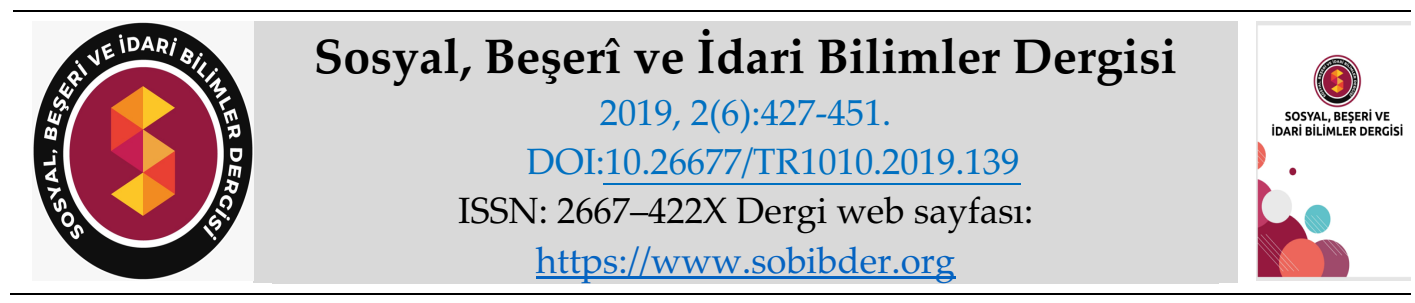

ARAȘTIRMA MAKALESI

\title{
Katalonya Eğitim Sisteminde Göçmen Öğrencilerin Okul Memnuniyetine İlişkin Bages İlçesinde Bir Alan Araştırması
}

Ebru KAYA, İstanbul Üniversitesi, Sosyal Bilimler Enstitüsü, Avrupa Birliği Anabilim Dalı, Avrupa Birliği Bölümü, Doktora Öğrencisi, e-posta: ebru.kaya@ogr.iu.edu.tr ORCID: https://orcid.org/0000-0002-4814-5669

Öz

Katalonya Özerk Topluluğu, İspanya'nın ikinci büyük nüfusa sahip ve göçmenler için çeşitli sebeplerden dolayı daha fazla tercih ettiği bir bölgedir. Hızla artan göç akışı, Katalonya sınıflarında yabancı kökenli öğrencilerin sayısı arttırmakla kalmamış, aynı zamanda öğrencilerin geldiği ülke sayısını ve dolayısıyla kültürel ve dilsel çeşitliliğini de büyük ölçüde genişletmiştir. Katalan Hükûmeti, göçmen öğrencilerin okula uyumunu sağlamaya yönelik planlar uygulamaya koymuştur. Bu çalışmanın amacı, Katalonya Özerk Topluluğu'nda, göçmen öğrencilerin okul memnuniyetini sağlamak için eğitim alanında harekete geçirdikleri temel politikaları inceleyerek, hedeflenen okul memnuniyetin gerçekleşip gerçekleşmediğini araştırmaktır. Bu çalışmanın verileri, literatür ve istatistiklere ilaveten İspanyolca dilinde yapılan anket çalışmasına dayanmaktadır. Çalışmaya katılan göçmen ebevynlerin değerlendirmeleri ışığında okul memnuniyetinin yüksek olduğunu söylemek mümkündür. Katalonya Özerk Topluluğu'nda, eğitim alanında harekete geçirdikleri politikalar ve göçmen öğrencilerin eğitimi alanına ayrılan kaynaklar ile bazı sorunlar çözümlenirken bazı sorunlar için çalışmalar devam etmektedir. Göçmen öğrencilerin okula uyumunda bir artışa ve bu alanda iyileştirmelere yol açacak okulların ve bir bütün olarak eğitim sisteminin işleyiş̧ine ilişkin bir dizi eğitim politikası önceliği ile bu alana yatırım yapılması gerekmektedir.

Anahtar Kelimeler: Katalan Eğitim Politikası, Göçmen Çocukların Eğitimi, Entegrasyon, Okul Memnuniyeti.

Makale Gönderme Tarihi: 25.04.2019

Makale Kabul Tarihi: 16.06 .2019

Önerilen Atıf:

Kaya, E. (2019). Katalonya Eğitim Sisteminde Göçmen Öğrencilerin Okul Memnuniyetine İlişkin Bages İlçesinde Bir Alan Araştırması, Sosyal, Beşeri ve İdari Bilimler Dergisi, 2(6): 427-451.

(c) 2019 Sosyal, Beşerî ve İdari Bilimler Dergisi. 


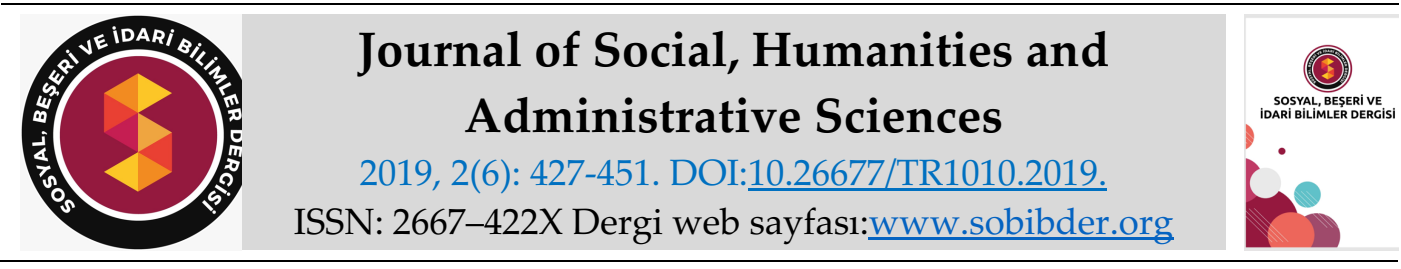

RESEARCH PAPER

\title{
A Field Research in the District of Bages Concerning School Satisfaction of Immigrant Students in the System of Education Applied in Catalonia
}

Ebru KAYA, Istanbul University, Institute of Social Sciences, Department of the European Union, Ph.D. Student, e-mail:ebru.kaya@ogr.iu.edu.tr

ORCID: https://orcid.org/0000-0002-4814-5669

\begin{abstract}
The Autonomous Community of Catalonia, which is the most populated region in Spain, is highly popular with immigrants owing to various reasons. The increasingly expanding community of immigrants has not only led to an increase in the number of students from different ethnical backgrounds in Catalonia but also greatly expanded the number of native countries and also the cultural and linguistic diversification of students. The Catalonian Government has implemented a number of plans meant to ensure adaptation of immigrant children to schools. The aim of this study is to examine the principal policies put into practice in the Autonomous Community of Catalonia in order to ensure the school satisfaction of the immigrant students and to investigate whether the targeted school satisfaction is realized or not. In addition to literature reviews and statistics, the data of this research is based on the data collected by the survey technique within the scope of qualitative method. It is possible to say that school satisfaction is high in the light of the evaluations of immigrant parents who participated in the study. While some problems have been solved by the policies implemented in consequences of the regulations on establishment of the structural framework of the integration by giving place to the integration and policy plans by Catalonia, studies are still in progress regarding some other issues. There is a need to invest in this area with a number of educational policy priorities for the functioning of schools and the functioning of the education system as a whole, which will lead to an increase in the integration of immigrant students into the school and improvements in this field.
\end{abstract}

Keywords: Catalan Education Policy, Education of Migrant Children, Integration, School Satisfaction.

Received: 25.04 .2019

Accepted: 16.06 .2019

Suggested Citation:

Kaya, E. (2019). A Field Research in the District of Bages Concerning School Satisfaction of Immigrant Students in the System of Education Applied in Catalonia, Journal of Social, Humanities and Administrative Sciences, 2(6): 427-451.

(C) 2019 Sosyal, Beşerî ve İdari Bilimler Dergisi. 


\section{GİRIŞ}

Göç, bir sistem halinde ve dünya çapında ülkeleri de içine alacak şekilde bağlantılı bir duruma gelmiştir. Bu durum göç alan ülkelerin toplum yapısını ve mevcut kaynaklarını da etkilemektedir. "Katalonya çeşitliliklerden oluşan bir Özerk Topluluktur. ${ }^{1}$ Daha önce hiç tecrübe etmediği kadar büyük bir ulus çeşitliliğine sahiptir." Katalonya Hükûmeti² (Generalitat de Catalunya), "Dünyanın en yoğun demografik değişikliklerden birini yaşayan, sosyal konsensüs çerçevesinde bir arada iyi bir seviyede bunu muhafaza ettiklerini ifade etmektedir" (Generalitat de Catalunya, Nota de prensa, 2016: 1-3). Öte yandan, ülkeye yeni gelen göçmenler ve bu göçmenlerin entegrasyonu genel nüfus çerçevesinde hesaplanmaktadır. Bu vatandaşların ne kadar kısa sürede uyum sağlayabildiği ise tartışmalı ve karmaşık bir konudur.

Katalonya Hükümeti'nin 2018 Ocak resmi verilerine göre, Katalonya'da 7.543.825 kişi yaşamakta olup, 1.079.712 göçmen sakini bulunmaktadır. Göçmen sakinler toplumun \%15'ini oluşturan önemi bir orana sahiptir (Generalitat de Catalunya Department de Treball Afer Socials i Families, 2017). ${ }^{3}$ Katalonya İstatistik Enstitüsü (Idescat) ${ }^{4}$ verileri, 2000 yılına kadar neredeyse 20 yll boyunca Katalan nüfusunun yaklaşık 6 milyon civarlarında sabit kaldığına işaret etmektedir. 2004 yılında Katalonya'ya başlayan büyük bir göç akımı ile 2010 yılına gelindiğinde göçmen sayısı 500 binden fazla kişiye ulaşmıştır. 2018/2019 eğitim-öğretim yılında, Üniversite eğitimini kapsamayan öğrenci sayısı ise, geçen yıla göre 1.299 kişi daha artarak, 1.567.316 öğrenciye ulaşmıştır (Idescat, 2018). ${ }^{5} \mathrm{Bu}$ gereksinimler eğitim politikalarında ve sistemlerinde birtakım dönüşümlere sebebiyet vererek, farklı kültürlerden gelen göçmen öğrencilerin ${ }^{6}$ eğitim kurumlarında okullaşma ve entegrasyonuna ${ }^{7}$ cevap aramalarına neden olmuştur.

\footnotetext{
${ }^{1}$ Idescat 2016 resmi verilerine göre, Katalonya'da 166 farklı uyruktan kayıtlı göçmen vardı. Bunların arasında, AB (423.178) ve Afrika (289.267) öne çıkmaktadır. Özellikle Afrika kökenli göçmenlerden 215.816 kişiyle Fas büyük bir çoğunluğa sahiptir. Akabinde Latin Amerika (192.479), Asya (151.330) ve diğer pek çok farklı uyruktan göçmen bulunmaktadır (Bkz. Generalitat de Catalunya, Institut de Estadística de Catalunya, 2018). 21979 yılında kurulan “Generalitat de Catalunya, İspanya'nın Katalonya Özerk Topluluğu'nun siyasi örgütlenmesidir."

${ }^{3}$ Bunlar sadece kayıtlı göçmen oldukları için istatistiksel verilerdir. Bununla beraber, tam istihdam verileri, ikamet ettikleri topluma katılım düzeyleri ve uyum seviyeleri, kültürel parametrelerine ilişkin veriler tam olarak tespit edilememektedir. Ek olarak, kayıt dışı "belgesiz” göçmenler konusunda çok kesin kabul edilebilecek veriler mevcut değildir.

${ }^{4}$ Katalonya İstatistik Enstitüsü: Idescat, Generalitat de Catalunya, Institut d’Estadística de Catalunya, Dades població Catalunya, 2018.

${ }^{5}$ Katalonya' daki göçmen okul çocuklarının büyük çoğunluğu, (\% 78.6'sı) ilk nesildir: İspanya dışında doğmuşlar ve ebeveynleri de İspanya dışında doğmuş olanlardır. Küçük bir oran (\% 21.4) ikinci nesil göçmenlerdir: İspanya'da doğmuş, göçmen ebeveynlerin çocuklarıdır (Conviviencia Cívica Catalana, 2015: 12).

' Farklı anlamları olan "göçmen" ya da "yabancı/vatandaş olmayan" olarak adlandırılan grup, bu çalışmada çalışmada ayrım yapılmadan kullanılacaktır.

${ }^{7}$ Entegrasyon kavramınına ilişkin net bir tanım bulmak pek kolay değildir. Sosyal bilimlerde, entegrasyon kavramı, bütünleşme, birleşme, uyum sağlama, kaynaşma olarak kullanılmaktadır. Kaiser ve Kaya (2016), entegrasyon kavramını sadece dil ve kültür unsurlarına indirgemenin doğru bir yaklaşım olmadığını vurgulamaktadırlar. Uyum olgusu, göçmenlerin toplum için değerli birer üyeye dönüşmesini ve politikaya, eğitime, ekonomiye tamamen dahil olmuş, ulusal toplumun kabul görmüş birer yasal üyesi olmalarını ifade etmektedir.
} 
Çalışmanın ilk bölümünde, kültürel, dini ve dilsel farklılıkların yönetimine dair ortaya konan yaklaşımlar tanımlanmıştır. İkinci bölümde, Katalonya eğitim sistemi genel bir çerçevede incelenmiştir. Daha sonra Katalonya'da eğitim politikaları ve Katalonya Özerk Topluluğu düzeyinde göçmen öğrencilerin okula uyumunu sağlamaya yönelik uygulanan planlara yer verilmiştir. Çalışmanın son ayrımında, Katalonya Özerk Topluluğu'nda yer alan Manresa şehri Bages ilçesinde göçmen öğrencilerin okul memnuniyeti araştırılmıştır.

\section{GÖÇMENLERE YÖNELİK ENTEGRASYON MODELLERI}

Günümüzde pek çok ülke kültürel açıdan çeşitlilik göstermektedir. Bugün çok az ülkede, yurttaşların aynı dili konuştukları ve aynı etnik ulusal gruba ait oldukları söylenebilir (Kymlicka, 1998: 25). Avrupa ülkelerinin göçmenlere yönelik entegrasyon modelleri olarak; asimilasyon, çok kültürcü, ${ }^{8}$ kültürlerarası ve kültürel farklılıkları dışlama yaklaşımı olarak farklı modeller uyguladıklarını söylemek mümkündür. Bununla birlikte, bazı politik seçeneklerde baskın olan veya esas olarak belirli toplumlarda uygulanan belirli özellikler vardır. Asimilasyonist model, entegrasyonu göçmen toplumu göç alan topluma uyarlama olarak kabul eder. Bu model; toplumların kültürel, etnik ve ırksal çeşitliliğini tanımasına karşın, bu çeşitliliğinin korunmasını değil, egemen ulusal kültürün içinde onu asimile etmeyi hedefler (Zapata-Barrero,2002 akt. Öztürk, 2016: 109). Bunun sebebi, kendi dilini, dinini ve kültürünü sürdüren göçmenlerin sosyal bütünlüğe tehdit olarak görülmesidir (Castles, 2007: 356, akt. Ceceli, 2012:14).

Çok kültürlülük ${ }^{9}$ etnokültürel çeşitliliği iyi hissettiren, vatandaşlara çok etnik grubun yaşadığı bir toplumda bir dizi geleneği, adeti ve müziği tanımaya ve kucaklamaya teşvik eden bir kutsama olarak karakterize edilmektedir (Kymlicka, 2012: 301). Çok kültürlülük, etnik, ırksal, dini ve cinsel olarak tanımlanan gruplar için eşit haklar ve tanınma arayışındadır. Eşitlik ve özgürleşme konusundaki vurgusu sebebi ile solun hareketi olarak görülmektedir. Çok kültürlülüğe toplulukçu bakış açısıyla bakan Charles Taylor, çok kültürcülüğü, otantiklik ve demokratik retoriğin özgünlüğün vurgulanması ve batılı evrenselciliği reddetmesiyle birleştiği bir "farklılık siyaseti" olarak tanımlamaktadır (Taylor, 1992: 53). Çok kültürcü model, kültürel kimlik hakkını ve birey ile gruplar arasındaki farkı savunur.

Kültürel çeşitliliğin yönetimine dayanan çok-kültürcü liberal model, kültürel azınlıkları asimile etmeyide, onların kendi kültürel kimliklerini ifade ettikleri alanları özel alan ile sınırlamayı da reddetmektedir. Bunun yerine, devletin tanımladığı, egemen ulusal, kültürel kimliğin dönüşümünü hedeflemektedir. Tek ulus ve tek kültür ile tanımlanan resmi kimlik yerine, var olan kültürel ve etnik çeşitliliği ifade eden resmi bir kimlik, çoğulcu bir vatandaşlık tanımlamasını öngörmektedir (ZapataBarrero, 2002 akt. Öztürk, 2016: 109-110). “Tüm modern liberaller, çok kültürcü politikaları ya da azınlıklara grup haklarının verilmesini destelemez. Örneğin, Brian Barry çokkültürcü politikalara karşı çıkmaktadır"' (Ceceli, 2012: 25).

\footnotetext{
${ }^{8}$ Bu çalışmada çokkültürlülük ve çokkültürcülü̈k birbirinin yerine kullanılacaktır.

${ }^{9}$ Kymclika'ya göre, bütün çok milliyetli indekslerde olduğu gibi, standardizasyon ve yerel farklara hassasiyet arasında bir dengeleme bulunur. "Çokkültürlülük politikası"nın evrensel çapta kabul görmüş bir tanımı bulunmamaktadır. Çokkültürlülük politikalarını ayrımcılık karşıtı politikalar, vatandaşlık ve entegrasyon politikaları gibi onlarla yakından bağlantılı politika alanlarından kesin hatlarla ayıran bir çizgi de bulunmamaktadır. Farklı ülkelerin (ya da aynı ülke içindeki farklı yetkililerin) bu çizgiyi farklı yerlere çizmesi olasıdır ve bu nedenle tartışmalı olması da muhtemeldir (Kymlicka, 2012: 305).
} 
İspanya'da 1990'lara kadar bu olgunun neredeyse kalıntı (residual) ve kurumsal yanıtın esas olarak asimilasyon modeline uyarlandığını söylemek mümkündür. Son on yıllık süre zarfında ise, Kymlicka aralarında İspanya, Belçika, Finlandiya, Yunanistan, Norveç, Portekiz ve İsveç' in olduğu birçok ülkede çok kültürlülük politikalarının güçlendiğini savunmaktadır (2012: 313). Yazarın, çok kültürlülügün Avrupada'da gücünü ölçmeye yönelik yaptığı çalışmada görüldüğü üzere, İspanya' daki ortalama skor 1980 'de $0^{\prime}$ dan, $2000^{\prime}$ de $1^{\prime}$ e ve $2010^{\prime}$ da $3.5^{\prime}$ e yükselmiştir. ${ }^{10}$

Kültürlerarası modeli incelediğimizde ise, entegrasyonun yabancı ve yerli kültürler arasında karşılıklı bir uyum süreci olması gerektiğini vurguladığını görürüz (Casas, 2004). Okul ortamında kültürlerarasılık sorunu göz önüne alındığında, üç ilginç teorik-pratik strateji üretilmektedir: telafi edici eğitim, çok kültürlü eğitim ve kültürlerarası eğitim (Besalú, 2011).

Gutiérrez, kültürlerarası eğitimin bazı temel ilkelerini, konuda uzman, (Muñoz Sedano, 1997; Essomba, 1999; Kincheloe y Steinberg, 1999; Besalú 2002, Martín Rojo,2003; Goenechea, 2005; García y Goenechea, 2009) farklı yazarların çalışmalarına dayanarak şu şekilde önermektedir.

- Sadece etnik veya kültürel azınlıklara hitap eden değil, herkes için bir eğitimdir.

- Kültürel çeşitlilik için ve bununla ilgili bir eğitim olmakla beraber, göreliliğin tanınması ve tüm kültürlerin sınıf dışı bırakılması.

- Toplumda mevcut çok kültürlülük bilgisini geliştirmelidir. Okuldaki çeşitli kültürleri ve dillerin varlığını ve kültürünü olumlu bir şekilde tanır.

- Kültürel farklılıklar, çoğunluk ya da azınlık, müfredatın bir parçası haline gelir. Bu farkı, olumlu ve değerli bir unsur olarak düşünülmelidir. Eğitimdeki kültürel çeşitliliği anlayan, ayırıcı bir unsur değil, aksine zenginleştirici, bütünleyen ve ifade eden bir unsur olarak görür.

- Kültürlerarası olarak eğitilmenin ilk adımı, farklı kültürel kökenlere sahip insanlar arasında bilgi, anlayış ve karşılıklı saygınlığı artırmak için gerçek olanaklar sunan fiziksel temasdır. İnsanlar başkaları tarafından kabul edilir ve kabul görürse, olumlu bir vasıta olarak fark yaratabilir.

- Eşit fırsatlar ve hakların savunulmasını talep eden iktidar ve zulüm yapılarını eleştirel bir analizle, ırkçı ve yabancı düşmanlığına dayalı ayrımcılıklara karşı aktif ve siyasallaştırılmış bir mücadeleyi içerir.

- En iyi kültürlerarası eğitim, kültürel azınlıkların toplumsal ve politik olarak tanınmasıdır. Politik ve sosyal sorunlara yalnızca eğitimsel çözümlerle cevap verilemeyeceğini savunur (Gutiérrez, 2012: 95).

Tüm bunlara ek olarak kısaca kültürel farklılıkları dışlama yaklaşımı ise, farklılıkları yok sayar ve sistem içinde var olmalarını hukuki, siyasi ve toplumsal açıdan kabul etmez (Ceceli, 2012 :12). Özetle, göçmenlerin ekonomik, politik, sosyal ve kültürel haklara sahip olması oldukça sınırlandırılmıştır.

Bir sonraki bölümde, Katalan eğitim sisteminin ve eğitim politikalarının yasalarla nasıl şekillendiği kısaca ele alındak sonra, göçmen öğrencilerin okula uyumu için Katalonya Özerk Topluluğu düzeyinde ortaya konan politika yaklaşımının ana hatlarını çizecek şekilde incelenecektir.

108 politik davranışın (uygulamanın) her birinden 1 puan alarak, ülkeler 8 puan toplayabilir. Ayrıntılı bilgi için bkz: (Kymlicka, W. 2012: 327). 


\section{KATALONYA ÖZERK TOPLULUĞU'NDA EĞİTIM SISTTEMINNE GENEL BAKIŞ}

Katalonya'nın zorunlu eğitim sistemi'nin ${ }^{11}$ genel çerçevesi, İspanya eğitim yasasıdır. Bu Özerk Topluluğun kendi Eğitim Departmanı (Departament d'Ensenyement) eğitim sisteminden sorumludur. Merkezî ve Katalan yönetimi, her biri kendi yönetim alanı kapsamında olan okul müfredatları ve okul ortamı ile ilgili olarak, İspanya toplumunu ve okul nüfusunu karakterize eden mevcut demografik çeşitliliğe yönelik bazı politika araçları ve yaklaşımları geliştirmiştir. Merkezî yönetimin ana yetkisi çeşitliliğin yönetimi ve temel okul müfredatının sadece bir bölümünün gelişmesidir. Katalonya yönetimi, kendi yönetim alanında olan dil ve kültürel çeşitliliği yönetir ve ayrıca müfredat geliştirmede yetkileri bulunur (European Commission, 2009). Bu özellik, müfredat, organizasyon, metodoloji ve değerlendirme hakkında farklı kararlar verebilecekleri anlamına gelir. Katalonya'da kamusal alanda Katalanca dili zorunludur. ${ }^{12}$

Karşılaşılan temel zorluklardan biri Katalonya Özerk Topluluğunda göçmen öğrencilerin coğrafi kökenine göre ülke çeşitliliğinin çok geniş olması ile ilgilidir. ${ }^{13}$ İstatistiksel veriler resmi kayıtlı vatandaşları veya vatandaşlık edinmiş olan kısmını ortaya koyarken temelde göç nedeniyle türeyen sorunlar ve uyum konusuna ilişkin, özellikle kültürel ve sosyal çeşitlilik açısından ele aldığımız Katalonya' da değişimleri açıklamakta yetersizdir.

Yabancı uyruklu öğrencilerin dağılımında en yaygın kriterler olarak belirlenen, ikamet yeri veya okullardaki boş yerlerin varlı̆̆ı, yabancı öğrencilerin belli okullarda daha fazla yoğunlaşmasını sağlamıştır (Calvet, 2011: 1585). Eğitim Bakanlı̆̆ı'nın verilerine göre, “2015-2016 eğitim-öğretim yılı Katalonya'da 135.797 göçmen öğrenci (\%79,8'i) devlet okullarına, geri kalan göçmen öğrencilerden \%13,2'si devletin sübvanse ettiği özel okullara (concertados), \% 7'si ise özel okullara kayıtlıdır." Bununla beraber, oranların kamu okulları lehine daha fazla olduğu iller ve ilçeler bulunmaktadır (Ministerio de Educacion, Cultura y Deporte, 2018: 6). MIPEX ${ }^{14}$ indeksine göre, düşük eğitimli anneleri olan yabancı uyruklu öğrencilerin, çoğu Batı Avrupa ülkesinde olduğu gibi İspanya'daki dezavantajlı okullarda yoğunlaşma olasılığı biraz daha fazladır (MIPEX, 2015).

Toplumun \%15'lere varan göç oranının farklı kültüre ve dine mensup göçmen sakinden oluşması Katalan toplumunda birçok farklı çocuk göçmenin kısa süre içinde eğitime uyumunu ve Katalan eğitim sistemini zorlayan unsurlardır. Göçmen öğrencilere ilişkin Katalonya' daki Eğitim Politikaları aşağıda dönemlere göre açılanacaktır.

\footnotetext{
${ }^{11}$ İspanya eğitim sisteminde; temel eğitim; ilkokul eğitimi (6-12 yaş), zorunlu ortaöğretim (I. devre 12-15 yaş), zorunlu ortaöğretim (II. devre 15-16 yaş) ücretsiz olarak verilmektedir. Zorunlu ortaöğretim sonrası fakülte eğitimi (Bachillerato) veya mesleki eğitim (Enseñanzas de Régimen Especial) gibi zorunlu eğitimi kapsamayan eğitimlere de devam edilebilir (Ministerio De Educación, Cultura y Deporte,2018).

${ }^{12}$ Müfredat kapsamında dil konusu: Katalan devlet okulunun araç ve eğitim-öğrenim dili Katalanca dilidir. Göçmen öğrencilerin dilsel olarak hazırlanması için ilköğretimde bu dilde yapılandırılmıştır.

${ }^{13}$ Mevcut iş olanakları, edinilen ekonomik kazanç, aynı ülkeden göç etmiş vatandaşların daha önce belli topluluklarda yerleşerek oluşturdukları ağlar, barınma ve kültürel faktörler İspanya dışında doğan yabancıların neredeyse \% 70'inin 17 Özerk Topluluğun sadece 4'ünde yoğunlaşmasına sebep olmaktadır.

${ }^{14}$ MIPEX: Merkezi Brüksel'de olan Göç ve Entegrasyonu Politika İndeksidir.
} 


\section{Kültürel Çeşitliliğin Eğitim Mevzuatı ve Kamu Politikalarına Dahil Edilmesi}

Kamu politikasının ne olduğuna ilişkin yanıtlar literatürde siyaset bilimciler tarafından farklı şekillerde verilmektedir. Kapsamı itibariyle en çok vurgulanan tanımın, Dye (2008) tarafından ortaya konan, "hükümetin yapmayı ya da yapmamayı tercih ettiği şey" tanımlamasıdır. Laswell ve Kaplan (1970) ise, amaç, değer ve uygulamalara yönelik bir program tanımlamasını yapmaktadırlar. Özer'e göre, teorik olarak, bir kamu politikasının varlığını araştıırken, ilk olarak, belirlenmiş bir amaç doğrultusunda belirli bir hedefe ulaşmak için program yapılıp yapılmadığı hususuna bakılmalıdır (2015: 63).

1. 1980-2000 Dönemi: 1980 'lerde demokrasiye geçiş ile İspanya, Özerk Topluluklara ayrılmıştır. Katalonya, Galiçya ve Bask Bölgesi'nin ortak özelliği, İspanyolca dışındaki dillere sahip olmalarıdır (Katalanca, Galiçyaca ve Baskça). 1980 ve 2000 yılları arası önemli konu yoğun göç akışlarıdır. Özerk Topluluklardaki göçün homojen olmadığı görülmektedir. Örneğin, Madrid ile karşılaştırıldığında, Madrid'e gelen göçü çoğunlukla Güney Amerika ülkeleri oluştururken, Katalonya'da göç olgusu daha fazla çeşitlilik gösterir. Katalonya çoğunlukla Fas ve Doğu bloku ülkelerinden göç almaktadır. Bu çeşitlilik sahip oldukları gelenekler, dinler, örf ve âdet farklılıkları sebebiyle önem taşır.

Katalonya yönetimi, kendi yönetim alanında olan dil ve kültürel çeşitliliği yönetmek için, politika önceliklerini belirlemiştir. 1990 yılı sonunda, İspanya Eğitim Bakanlığı'nın, öğrencilerin okullara tam uyumunu desteklemek için telafi edici eğitim programının ${ }^{15}$ Generalitat Eğitim Departmanı'na devredilmesini içeren bir anlaşma imzalanmıştır. Bu telafi edici eğitim programı ile göçmen öğrenciler ve Roman vatandaşlar özel olarak ele alınmak suretiyle ayrıcalıklı duruma gelecekti (Calvet, 2011: 1586).

1992 yılında, Generalitat Eğitim Departmanı, ilköğretimin müfredatını (Departament d'Ensenyament, 1992) ve zorunlu ortaöğretimi (Departament d'Ensenyament de la Generalitat, 1992a) belirlerken kültürlerarası uyum ilkesini referans olarak almıştır (Calvet, 2011: 1586).

1993 yılında, Göçmenlik Planı'nın onayı (Departament de Benestar Social, 1993), diğer bölümlere ek olarak, kültürlerarası alanda özellikle öğretmenlerin formasyonunu içerir. Katalonya'da kültürlerarası söylemin geliştirilmesinin nedeni, kamu okullarına ait sınıflardaki göçmen öğrencilerin belirgin ölçüde artması ve Avrupa Birliği'nin etkisidir. 1993-1994 ve 1995-1996 yıllarında, Avrupa Konseyinin yabancı düşmanlığı ve 1 rkçılık sorunlarına verdiği tepki doğrultusunda çeşitli kararlar verilecektir. Uygulamaya bakıldığında, Katalan Yönetimi'nin okuldaki kültürel çeşitliliğe ilişkin verdiği yanıt ise sınırlıdır. Sınırlı olmakla beraber, yıllardır işleyen telafi edici eğitim programının katkıları dikkate alınmalıdır. "Kültürel farklılıklara karşı artan duyarlılıktan kaynaklanan farklı deneyimler, bu konuda eğitim kursları, derneklerin ve çeşitli kurumların desteği, uluslararası sözleşmeler ve destekler, eğitimde kullanılmak üzere hazırlanan materyaller ve kaynaklar örnek olarak verilebilir" (Calvet, 2011: 1587).

1996 yılına gelindiğinde ise, kültürlerarası eğitim konusundaki bu modele doğru ilerleme kendini daha net olarak göstermiştir. Katalan toplumunda eğitim politikalarının, yeni nesilleri yaşama hazırlaması gerektiği, tüm öğrencilerin kendi kültürleri ve bu bağlamda gerek toplumda gerekse okulda var olan kültürel çeşitlilikle ilgili bir dizi politika geliştirme amacı daha kabul edilmiştir (Calvet, 2011: 1587).

\footnotetext{
${ }^{15}$ Programın odak noktası sosyo-ekonomik, coğrafi ve kültürel eşitsizlikle mücadele etmektir.
} 
2. 2000 sonrası Dönem: 2000 sonrası, bu genel eğilimin yeni basamağı olan değiş̧im ve dönüşüm, bu dönemde Yabancı Uyruklu Öğrenciler için Eylem Planı'nın (Plan de Actuación para el Alumnado de Nacionalidad Extranjera, 2003) yürürlüğe girmesidir. Bu eylem planı ile özel önlemlere geçiş ve "normalleşme", "özerklik", "uyum", "iç ve diş hizmetlerin koordinasyonu" vb. gibi kavramlar lehine özel bir vurgu yapılmıştır (Canosa, 2011: 538).

Navarro'ya göre, 2004 yılından sonra kurulan sol hükümetler, eğitim sisteminde, özellikle de kamu okullarının gelişmesinde önemli değişiklikler yapmışlardır. Üçlü hükümet, 2004 yılından bu yana, kamu eğitim harcamalarında artış anlamında önemli değişiklikler yaptı. Devlet okullarının önceki hükümette bulunmayan bir öncelik haline geldiği açıktır. Fakat, kamu sübvansiyonlu özel okulların öğrencileri seçme gücü kaldırılmazsa, göçmenler ve emekçi kesimin çocukları okullarda ayrımcılığa uğradıkça, bu toplumsal ve sosyal kutuplaşmanın Katalonya'da devam edeceği konusu endişe vericidir (Navarro, 2009).

Katalonya'da devam etmekte olan politika önceliklerinden; eğitimde dil politikaları, telafi etmeye yönelik eğitim destekleri aşağıda açıklanacaktır.

\section{Eğitimde Dil Politikası}

Katalan Yönetimi, 1978 Anayasasından itibaren, tüm kamusal alanda ve medyada İspanyollara karşı dezavantajlarının üstesinden gelebilmek için dilbilimsel normalleşme sürecini başlamıştır. ${ }^{16}$ Okullarda "normalización Lingüística" Projesi Katalanca'yı resmi araç dili olarak belirlemiştir. Bu proje aynı zamanda okula başlayan göçmenlere yöneliktir. İlköğretim düzeyinde Katalanca dilinin kullanımı hızla yaygınlaştırılmıştır. Daha ileri bir yaşta eğitim alan öğrencilerin seviyelerinin farklı olduğu ve ilköğretimin orta düzeyinden itibaren Katalanca konuşmayan öğrencilerin de katılması için 1996 yılında ortaya konan geç birleşme programı (Programa de Incorporación Tardía) oluşturulmuştur. Katalanca dili ile daha önce tanışmamış olan öğrencilere yönelik olan bu program, ilk yılda (puanlamasız olarak) Katalanca dil eğitimi verilmesinden oluşur. ${ }^{17}$ İkinci yılda özel bir değerlendirmeye dahil olurlar. Esnek değerlendirme kriterleri olsa bile öğrenciler normallikle bütünleşirler. Buna ek olarak, okul dışı saatlerinde köken dil sınıflarının organizasyonun düzenlenmesi için sivil toplum kuruluşları ile iş birliği anlaşmaları yapılmıştır, ancak bu konu uygulama pek yaygınlaştırılamamıştır (González, 2013: 81; Calvet, 2011: 1588).

Katalonya'da, dilsel nedenlerle iki veya üçlü eğitim ağı bulunmamaktadır. Öte yandan, bu eğitim sisteminin, politik olarak, Katalonya'nın ulus kimliği, kültürü ve sosyal bütünlügü için ne kadar faydalı olduğu vurgulanmaktadır. "Her ne kadar belirtilen hedef kültürlerarasılık olsa da özünde asimilasyon uygulamaları yoluyla entegrasyon sürdürülmektedir" (European Commission, 2009). Katalan ulus kimliğine ilişkin en önemli göstergelerden biri Katalanca dili konuşabilme yeteneğidir

16 “Katalan bölgesi, Franco rejimi öncesinde (1931-1939) yılları arasında, daha geniş bir özerklikten yararlanmaktaydı. Franco rejimi bu özerkliği tamamen kaldırarak diğer bölgelerde uyguladığı şekilde Katalonya' da dilsel özgürlükleri tamamen kısıtlamıştır. Katalan toplumu, dillerinin kullanımı bakımından daha geniş yetkilere sahiptir. Katalonya, 1978'lerde başlayan demokratikleşme ve özerk topluluklaşma sürecinde özerklik haklarını yeniden edinmiş ve Katalanca dilinin tekrar canlandırılabilması için çalışmalarını bu konuda önceliklendirmiştir. Katalonya Özerk Statüsü, 1979 yasasının 3. maddesine göre, Katalonya'nın dili Katalanca'dır" (Tunçay, 2016: 52).

17 Öğrenciler en fazla iki yıl içerisinde dil yeterlilik sınavından geçerli not almak zorundadırlar. 
(Tunçay, 2016: 52). Artola'nin görüşüne göre de Katalonya' da en iyi işlemiş olan iki mesele, Katalanca dilinin öğrenilmesi ve durumlarını yasal hale getiremeyenler için erişim kriterlerinde eşitlik olmuştur (2009: 272). Diğer bir görüşe göre, Katalonya'daki yoğun uygulama "Immersió Lingüística" toplumu kapsamaz, tam tersine ayrıştırır. Bu, İspanyolca konuşan ve Katalanca konuşan öğrenciler ve aynı zamanda göçmen öğrenciler ve yerli öğrenciler arasındaki eğitim performanslarında kırılmayı tetikler (Convivencia Cívica Catalana, 2016: 42).

Convivencia Cívica Catalana'dan alıntıladığım görüşüne karşıt olarak, yaptığım görüşmelerde öğretmenler, "Immersió Lingüística Programı"nın göçmen öğrencilerin gerek okula gerekse topluma uyum sağlamalarında dikkate değer bir katkısı olduğu görüşündedirler. ${ }^{18}$

Katalan hükümetlerinin okula uyumu hızlandırmaya ilişkin oluşturduğu sistem aşağıda açıklanacaktır.

\section{Telafi Etmeye Yönelik Ĕ̆itim Destekleri}

Eğitim departmanı, 1998-1999 yıllarından itibaren, eğitim sistemine geç başlayan öğrencilerin gereksinimlerini karşılamak ve okula uyum sağlayabilmeleri için hazırlık sınıflarını bu öğrencilerin hizmetine açmıştır (González, 2013: 81-83). Bu sınıflar, göçmen öğrenci oranı yüksek olan okullarda, bu öğrencilerin öğrenimlerini kolaylaştırabilmek ve hızlandırmak amacıyla Katalanca dil eğitimi vermektedir.

Elde ettiğimiz veriler ışığında, hazırlık sınıfları, yabancı kökenli öğrencilerin kabul edilmesi ve ek destek girişim çizgisinin en önemli temsilcileridir (Castaño, Gómez y Bouachra, 2008: 34). Okullara göre değişlik gösteren büyüklükteki hazırlık sınıfları Dil ve Sosyal Uyum (Llengua i Cohesió Social LIC $)^{19}$ kadrosundan eğitim alan, dil bilmeyen öğrencileri normal sinıflara hazırlayan bir sinıf öğretmeni atanmaktadır (Calvet,2011: 1588). Katalonya'da, 2004 yılından beri yeni gelen öğrencilerin Katalanca dil okula uyumunlarını teşvik etmek için Katalanca dil desteği veren bu sınıflar ilk ve ortaöğretim okullarında bulunur. Bu sınıfların etkinliğinde iki temel gösterge bulunur: Katalanca dile hakimiyet ve okula uyum (Vila, Canal, Mayans vd., 2009: 308; Escandell, 2013: 169).

Bu program, eğitime başlayan ve iki resmi dili (Katalanca ve İspanyolca) bilmeyen yabancı kökenli öğrencilerin dil öğrenmesi, okula uyumu ve okul alışkanlıkları konusunda eğitirken, yanı sıra, matematik, sosyal ve doğal çevre bilgisi gibi derslerin verilmesini de içerir. İngilizce, Müzik, Beden Eğitimi gibi Katalanca dil bilgisinin gerekli olmadığı dersler normal sınıflarda verilir (Calvet,2011: 1588).

\footnotetext{
${ }^{18}$ Manresa Bages ilçesinde öğretmenlerle gerçekleştirdiğim görüşme notlarımdan çalışmaya aktarılmıştır. MartNisan 2018.

19 “2003-2006 yılları arasında yabancı uyruklu öğrencilere ilişkin önlemleri içeren Dil ve Sosyal Uyum Planı ${ }^{19}$ (Pla d'actuació per a l'alumnat de nacionalitat estrangera 2003-2006) ${ }^{19}$ açıklanmıştır. Bu planın amacı, yabancı kökenli öğrencilerin eğitim sistemine tam olarak katılmalarını sağlayarak, köken dili, kültürü, sosyal statüsü ne olursa olsun okula ve sosyal çevreye uyum sağlayabilmeleridir. Eğitim alanındaki değişimin simgesi olan Dil ve Sosyal Uyum Planı kadrolarının oluşturulmasıyla hayata geçirilmeye başlamıştır (Serra, 2006: 165; Canosa, 2011: 538; Barrero and Witte, 2007: 18). Katalonya Eğitim Departmanı bu planının uygulanması ile Katalonya nüfusunun kültürel çeşitliliğini dikkate alan ve odağında eğitim olan bir yerel çevre yaratmayı amaçlamıştır. Bütün öğrencilerin okul başarısına yardımcı olmak ve marjinalleşmeyi önlemek amacıyla okulların yerel eğitim planları bu kapsamdadır" (European Commission, Emilie Project Final Report, 2009).
} 
Hazırlık sınıflarına ilişkin en tartışmalı olan konulardan biri, öğrencilerin ayrımcılığa uğradığı konusuna ilişkindir. Calvet'e göre, hazırlık sınıfları da dahil olmak üzere, sınıflardaki yoğunluk, yüksek oranda göçmen öğrencisi bulunan eğitim görevlileri tarafından doğrulanmış ve bu durumda yeni gelen öğrencilerin geçici olarak ayrılmasını tercih etmelerine yol açmıştır. Öyle görünüyor ki, mevcut eğilim, çok sayıda göçmen öğrenci ile çalışmanın ve dönemin farklı zamanlarında kurumlara ve sınıflara ulaşma konusundaki direniş ve zorluklarla karşı karşıya kaldığı gibi, yıllar önce Roman vatandaşlara yapılanlara benzer geçici ayrımcı uygulamalara dönüşü savunur.

Yukarıda vurgulanan ve alıntı yapılan son çalışmalar, olguyu yönetmenin başka yollarının olduğunu, engelleri aşan ve zor durumları dikkate değer başarılara dönüştüren öğretmen ekipleri olduğunu göstermektedir. Böylece, göçmen öğrencilerin yüksek oranda varlığı, insan kaynaklarının artmasından kaynaklanan dinamikler, yönetim kadrosu, öğretmenler, öğrenci anne ve babaları derneği ve öğrencilerin aileleri çaba harcamadan, terk edilmeyi tetikleyen bir durum haline gelmesi (öğrencilerin, ailelerinin ve öğretmenlerin bir kısmının belli okullardan çekilmeleri gibi örnekler) benzer sorunlara sahip diğer okullara atıfta bulunmaya davet eden bir durumdur (Calvet, 2011: 1588).

Katalonya'nın hazırlık sinıflarının genel prensipleri, okulların somut kullanımı tek bir modele cevap verebilir durumda değildir. Bu nedenle, yabancı kökenli öğrencilerin ihtiyaçlarına, sosyo-dilbilimsel içeriğe ve okula uyum sağlamaları için Katalanca dil bilgisini teşvik ederken, aynı zamanda, yabancı kökenli öğrencilerin Katalan okullarına uyumu teşvik eden organizasyonel önlemlerin uyarlanması gerekmektedir (Vila vd., 2019: 326).

Son yıllarda Katalonya' daki en önemli dönüşümü, başta AB, Afrika, Latin Amerika ve Doğu Avrupa olmak üzere diğer ülkelerden gelen milyonlarca insan oluşturur. Dolayısıyla dünyanın farklı bölgelerinden gelen insanlar, kültürel çeşitliliğin artmasına sebep olur. Değiş̧ime etki eden bu kültürel çeşitlilik yirmi yıldan kısa bir sürede Katalan eğitim sistemini yeni koşullara maruz bırakır. Bu yeni koşullar, özellikle göçmen ailelerin çocuklarının eğitimi ile ilgilidir. Bu da Katalan eğitim sisteminin yeniden gözden geçirilmesi demektir. Bu çalışmayı önemli kılan bir husus bu konuda Türkiye'de detaylı bir çalışmanın olmamasıdır. Bir diğer husus da çalışmanın ilgili literatüre bir Avrupa Birliği Üye Devletinin Özerk Topluluğu'nda göçmen öğrencilerin okula uyumuna ilişkin ne gibi düzenlemeler ve uygulamalar yapıldığı konusuna ışık tutmasıdır. Bu kapsamda Katalonya Özerk Topluluğu'nda yer alan Manresa şehri Bages ilçesinde göçmen öğrencilerin okul memnuniyeti araştırması bir alt bölümde incelenmiştir.

\section{ARAŞTIRMANIN AMACI}

Bu araştırmanın amacı, Katalonya Özerk Topluluğu'nda, göçmen öğrencilerin okul memnuniyetini sağlamak için eğitim alanında harekete geçirilen temel politikalar doğrultusunda, hedeflenen okul memnuniyetinin gerçekleşip gerçekleşmediğini saptamaktır.

\section{YÖNTEM}

Temel olarak literatüre dayalı yürütülen çalışmada, hazır bilginin yanı sıra İspanyolca, İngilizce ve Katalanca uluslararası literatürde yer alan araştırmalar ile istatistiklerden de yararlanılmaktadır. 
Bunlara ilaveten bu çalışmanın verileri, Bages ilçesinde göçmen ebeveynlerle yüz yüze görüşülerek İspanyolca dilinde yapılan anket çalışmasına dayanmaktadır. Veriler, 2018 yılı Ekim- Kasım döneminde 30 kişilik bir örneklemden elde edilmiştir. Bu çalışmada anket yapılan her bir ebeveyn, bir sonraki ebevyne ulaşmamızı sağlamıştır. Bu şekilde ebevynler arasındaki ağlardan faydalanılmıştır. Çalışmanın kapsayıcılığını artırmak amacıyla, anket yapılan kişilerin yardımı ile gerek okul gerekse köken farklılıkların daha belirgin elde edileceği yeni katılımcılara ulaşılmıştır.

Veri toplama aracı olarak kullanılan anketin güvenilirliliği SPSS programıyla ile saptanmıştır. Cronbach Alpha güvenilirlik katsayısı 0.86 'dır ve yüksek güvenilirlik düzeyindedir. Katılımcıların anket sorularına verdikleri cevapların geçerli oldukları varsayılmıştır.

Araştırmada veri ve bilgilerin toplanması için geliştirilen bu anketin içeriği beş temel bölümden oluşmaktadır. Bu soruların temel amacı, Katalonya eğitim politikaları, güncel eğitim sisteminin işleyişi, katılımcıların görüş ve tavsiyeleri hakkında bilgi almaya yöneliktir. Bu sorular doğrultusunda alınan cevaplar çalışmaya yansıtılmıştır. Soruların ana teması: Katalonya Özerk Topluluğu'nda verilen eğitim sisteminin, göçmen öğrencilerin okul memnuniyetinin değerlendirilmesine ilişkindir.

Birinci bölümde katılımcıların genel özelliklerini yansıtacak 10 soru yönetilmiştir. İkinci bölümde eğitim-öğretim kurumu ile iletişim derecesi, eğitim topluluğuna katılımı ve entegrasyonu ile ilgili 13 soru yönetilmiştir. Üçüncü bölümde ise, bilgiye erişmede kolaylık derecesini içeren sorular yönetilmiştir. Dördüncü bölümde eğitim kurumu ile ilgili memnuniyet değerlendirmelerini ve son bölümde katılımcıların beklentilerini içeren sorulara yer verilmiştir. ${ }^{20}$

\section{Araştırmanın Evreni, Örneklemi ve Sınırlılıkları}

Bu araştırma 6-20 yaş arası düzenli göçmen öğrencilere odaklanmaktadır. Bu araştırmada, Katalonya Özerk Topluluğu'ndaki mevcut duruma dayanarak, göçmen öğrencilerin okul memnuniyetini sağlamak için eğitim alanında harekete geçirdikleri temel politikalar çerçevesinde, hedeflenen okul memnuniyetin gerçekleşip gerçekleşmediği Katalonya Özerk Topluluğu'nda yer alan Manresa şehri Bages ilçesinde 30 göçmen ebeveyn üzerinden incelenmektedir. Ankete Fas'tan 12, Romanya'dan 8, Latin Amerika ülkelerinden 8 (Arjantin, Venezuela, Ekvador, Bolivya) Hindistan'dan 2 kişi katılmıştır. Ankete katılanlar büyük çoğunlukta, kamu okullarında ilköğretim (14) ve zorunlu öğretimde ikinci evre (16) eğitim düzeylerinde öğrencilerin ebeveynleri olmuştur. 30 ebeveynin, büyük oranda zorunlu eğitim aşamasını tamamlamış olduğu, ancak 3 Fas kökenli ebeveynin herhangi bir eğitim almadığı veya ilkokulu bitirmediği belirtilmelidir.

Bages ilçesinin seçilmesinin nedeni, göçmen öğrencilerin coğrafi kökenine göre ülke çeşitliliğinin çok geniş olması ve göçmen öğrencilerin oran olarak en yüksek olduğu ilçelerden biri olmasıdır. ${ }^{21}$ Çalışmanın örneklem sınırlılığından dolayı Katalonya'nın bütününü içeren bir çalışma değildir. Bu nedenle, sonuçlar genellenemez.

\footnotetext{
${ }^{20}$ Anketlerle ilgili daha detaylı bilgi ve tercümeleri için bkz. Ek 1 ve Ek 2.

${ }^{21}$ Ayrıntılı bilgi için bkz. Katalonya Ulusal İstatistik Kurumu

https://www.idescat.cat/emex/?id=081136\&lang=es
} 


\section{Verilerin Analizi}

Anketler, katılımcıların çalışmada odak kriterlerini doğruladıktan sonra ayrıntılı bir veri temizliğine tabi tutulmuştur. Aynı şekilde, anketi asimile etmek için çok düşük olduğu düşünülen sürede yanıtlananlar ve bu çalışmada odaklanan yaş grubu dışında kalan katılımcıların yanıtları da elenmiştir. Elde edilen yanıtlar SPSS programıla frekans ve çapraz tablolar ile analizler yapılarak şu bulgulara ulaşılmıştır.

\section{BULGULAR ve YORUM}

\section{Ĕ̆itim-Öğretim Kurumu ile İletişim Derecesi ve Eğitim Topluluğuna Katılım}

Ebeveynlerin neredeyse tamamı okul müdürünü (\%81), okul idaresini ve danışmanını tanıdığını ve çocuklarının öğretmeni ile çeşitli defalar $(\% 85,7)$ konuştuğunu belirtmiştir. Bu ziyaretlerin nedenleri çocuğun uygunsuz davranışlarından/uyum sorunundan ziyade çoğunlukla kendi inisiyatifleridir. Bir ebeveyn hariç tüm ebeveynler, okul tarafından yürütülen faaliyetler hakkında sürekli bilgi aldıklarını (\%81) ve tamamı (\%100) okulla iletişim sorunları yaşamadıklarını belirtmişlerdir. Bu ebeveynlerin, okula entegrasyonda çok önemli katkıları bulunan Öğrenci Anne ve Babaları Derneği'ni (AMPA) ${ }^{22}(\% 66,7)$ oranında tanımakta ve orta derecenin biraz üzerinde katılımda bulunmaktadırlar. AMPA'ya üye olamayanların en önemli nedenleri: zaman yetersizliği $(\% 61,9)$ ve ilgisizlik (\% 9,5), tanımayan ebeveyn oranı ise sadece $(\% 4,8)^{\prime}$ dir. Okul etkinliklerine (tiyatro, eğlenceler vb.) katılım oranlarınları ise, orta düzeydedir.

Son olarak, okul idaresi temsilcilerinin seçimine katılmanın çok önemli olmadığı görüşündedirler. Ebevnyler çocuklarının eğitim etkinliklerine katılmaları, öğretmene bireysel ziyaretleri, velilerin toplantılarına katılmaları ve ev ödevi yapmalarına yardımcı olmanın önemli olduğunu düşünmektedirler. 11 ebeveyn, çocuklarının ödevlerini yapmalarına yardım ettiklerini, öğleden sonraları okul destek sınıflarına gittiklerini ifade ederek ev ödevlerine yardımcı olmanın önemli olduğunu belirtmiştir.

Okul seçimini etkileyen faktörler arasında en önemli husus ev ya da işyerine yakın olmasıdır. Ayrıca, en önemli kriterler, öğretim personelinin kalitesi ve okulun hizmetleri ve donanımları olduğunu yanıtları verilmiştir. Okul seçiminde etki eden faktörler ile ilgili, "kendilerine uyumlu değerleri yansıtan bir kurum olması" $(\% 66,7)$ çok, $(\% 28,6)$ orta ve $(\% 4,8)$ az, "bu kurumda okuyan öğrencilerin türü", $(\% 28,6)$ çok, $(\% 42,9)$ orta ve $(\% 28,6)$ az, "kendi ülkelerinden aileler bu okulu seçtikleri için" $(\% 66,7)$ az, $(\% 19,0)$ orta ve $(\% 14,9)$ çok oranlarında yanıtlar verilmiştir. Bu sonuçlar, okulun (idari) veya grubun kimlik işaretlerinin katılan göçmen sakinlerin okul seçiminde esas belirleyici faktör olmadığını göstermektedir.

\section{Bilgiye Erişim Kolaylı̆̆ı}

Ebeveynlere, bilgiye erişmede kolaylık hususunda memnuniyet dereceleri sorulmuştur. Elde edilen sonuçlar şöyledir: Okul öğrenimi sürecinde işlemler ve kabul kriterleri hususunda bilgiye erişim

22AMPA: Las Asociaciones de Madres y Padres de Alumnos. 
kolaylığ1 mevcuttur. $(\% 57,1)^{\prime}$ si, bu süreçte ki hizmetlerden çok memnun olduğunu ifade ederken, $(\% 28,6)$ orta, $(\% 14,3)$ ise az memnun olduğunu belirtmiştir. Öğrenim denkliği tanımada bilgiye erişim kolaylığını ve gerekirse eğitim kurumunu değiştirmede kolaylık mevcuttur. Çalışmaya katılan ebeveynlerin çoğunluğu $(\% 70,83)$, İspanyolca konuşmayı bilemeyen ebeveynler için bir tercümanın var olduğu konusunda $(\% 42,9)$ orta, $(\% 38,1)$ az ve $(\% 19,0)$ çok oranları saptanmıştır. Ebeveynler bu desteğin yeterli olmadığını adeta doğrulamıştır. Çoğu durumda, tercümanların işlevini gören çocuklardır.

\section{Okulla İlgili Memnuniyet Derecesi}

Çocuklarının aldığı eğitim kapsamında memnuniyet derecelerine ilişkin yöneltilen sorularda; okuldaki çalışma ortamı, öğretmenlerin öğretme şekli, öğrencilerin aldığı hazırlıklar, velilerin okula katılımı, okul idaresinin işlevi, aileler ve öğretmenler arasında iletişim, öğretmenlerinin ailelere gösterdiği özen, eğitim kurumunun donanımı, araç ve gereçleri (yemekhane, spor salonu, kitaplık, vs.), eğitim kurumunun yansıttı̆̆ı değerler ve çocuklarının aldığı eğitimin beklentileri karşılayıp karşılamadığı konularındaki yanıtlar; genel olarak beklentilerine yakındır. Aşağıdaki Tablo 1'de eğitimin beklentileri karşılayıp karşılamadığına ilişkin saptamalara yer verilmiştir.

Tablo 1. Ebeveynlerin Memnuniyet Dereceleri

\begin{tabular}{|c|c|c|c|c|c|}
\hline \multicolumn{3}{|c|}{$\begin{array}{l}\text { Çocuğumun aldığı eğitim beklentilerimi } \\
\text { karşılıyor }\end{array}$} & \multicolumn{3}{|c|}{ Öğretmenlerin öğretme şekli } \\
\hline & Siklık & $\%$ & & S1klık & $\%$ \\
\hline $\mathrm{Az}$ & 1 & 4,8 & $\mathrm{Az}$ & 1 & 4,8 \\
\hline Orta & 9 & 42,9 & Orta & 20 & 52,4 \\
\hline Çok & 21 & 52,4 & Çok & 9 & 42,9 \\
\hline Toplam & 30 & 100,0 & Toplam & 30 & 100,0 \\
\hline \multicolumn{3}{|c|}{ Okuldaki eğitim ortamı } & \multicolumn{3}{|c|}{ Öğrencilerin aldığı hazırlıklar } \\
\hline & Siklık & $\%$ & & Siklık & $\%$ \\
\hline $\mathrm{Az}$ & 1 & 4,8 & $\mathrm{Az}$ & 3 & 14,3 \\
\hline Orta & 17 & 38,1 & Orta & 7 & 33,3 \\
\hline Cok & 12 & 57,1 & Cok & 20 & 52,4 \\
\hline Toplam & 30 & 100,0 & Toplam & 30 & 100,0 \\
\hline
\end{tabular}

Değerlendirmede $(\% 52,4)$ çok memnun, $\left(\% 42,9^{\prime} u\right)$ normal/orta ve $(\% 4,8)^{\prime}$ i tatmin edici değildir/az şeklinde sonuçlar saptanmıştır. En önemli faktörler arasında öğretmenlerin ailelere gösterdikleri özen, öğrencilerin aldığı hazırlıklar, okuldaki çalışma ortamı ve öğretmenlerin eğitim-öğretim yöntemleri yer almıştır.

En az olarak değerlendirilen faktör ebeveynlerin katılımı iken, okul idaresinin işlevi ve eğitim kurumunun yansıttığı değerlerdir. 


\section{Beklentiler}

Bu bölümde, ebeveynlere beklentilerine ilişkin bir dizi soru sorulmuş ve kabul edip etmedikleri, kayıtsız kaldıkları veya onlarla aynı fikirde olmadıkları konuları ifade etmeleri istenmiştir. Bu sorular okulla ilgili düşünceler, çocuklarının zorunlu eğitim aşaması tamamlandığında, yüksek eğitime devamı ve geleceği hakkındaki düşünceler, çocuklarının kariyerleri ve ekonomik krizin eğitime yansımalarına ilişkin kaygılarla ilgilidir.

Okula İlişkin Yaklaşım: Ebeveynler, ırkçılığın, yabancı düşmanlığının ve ayrımcılığın önüne geçilmesi hususunda öğretim kurumları girişimlerde bulunmalıdır konusunda hemfikir kabul edilebilir. (\%71,4) katıldığını, (\%19,0'u) katılmadığını belirtmiştir. (\%9,5)'i ise kayıtsız kaldığını belirtmiştir. (\%71,74)'ü çocuklarının öğretmenlerinin sadece akademik güçlüklere değil aynı zamanda kişilere, sevgiye ve birlikte yaşamaya da bakması beklentisindedirler. Karar verme sırasında eğitim kurumlarında aileler ile görüşmek üzere kendilerine ilgi gösterilmesi konusunda, $(\% 81,0)$ katılırken, $(\% 9,5 ’ u)$ kayıtsız, $(\% 9,5)$ ise katılmadığı görüşündedir.

Ĕ̆itimin Geleceği ve Mesleklere İlişkin Yaklaşım: Ebeveynlerden 26'sı çocuklarının üniversite eğitimi almasını istediklerini ifade etmişlerdir. 3 ebeveyn kayıtsız kalırken (özellikle kız çocuklarına ilişkin), 1 ebeveyn katılmadığını belirtmiştir. Tahsili tamamladıktan sonra çocuklarının kendi ülkelerine geri dönmesini istemeyen ebeveynler (\%81) oranındadır. Aşağıdaki tabloda bu konuya ilişkin anket sonuçlarının yüzde olarak dağılımları verilmiştir:

Tablo 2. Tahsili tamamladıktan sonra çocuğumun kendi ülkeme geri dönmesini isterim

\begin{tabular}{|l|l|l|}
\hline & S1klık & \% \\
\hline Katılmıyorum & 27 & 81,0 \\
\hline Katılıyorum & 3 & 19,0 \\
\hline Toplam & 30 & 100,0 \\
\hline
\end{tabular}

Gelecekteki istihdam konusu ilgili soruya ilişkin olarak ise, zorunlu eğitimi bitirir bitirmez çalışmasını isteyen ebeynlerin $(\% 23,8)$ bu yaklaşıma katılırken, $(\% 14,1)$ 'si kayıtsız, $(\% 23,8)$ ise katılmadığını ve eğitime devam etmesini istiyorum şeklinde ifade etmişlerdir.

Ekonomik Krize İlişkin Görüşler: Eğitimde, yönetim kesinti yapmamalıdır konusunda, katılımcıların (\%71)'si aynı fikirde olumlu yanıt vermiştir. Ekonomik kriz nedeniyle eğitimin kötüleşebileceği yönündeki açılamalar konusunda 6 ebeveyn kaygı duymazken, 5 ebeveyn orta, 1 ebeveyn ise ciddi oranda kaygılıdır. Son olarak, önümüzdeki dönemlerde gıda ve kitap yardımı yapılmamasından orta düzeyde endişe duyarlarken ve eğitim hayatlarında burs verilmemesinden/kesintiye uğramasından daha yüksek oranda $(\% 71,4)$ endişe duydukları saptanmıştır.

Öte yandan, kriz nedeniyle eğitimdeki kesintilere rağmen, çocuklarının İspanya'da tahsil görmesini tercih edeceklerini ifade eden ebeveynlerin oranı $(\% 57,1)$ olarak saptanmıştır. Bu sonuçlar aşağıdaki tabloda sunulmaktadir: 
Tablo 3. Eğitimdeki kesintilere rağmen çocuğumun İspanya' da tahsil görmesini tercih ederim

\begin{tabular}{|l|l|l|}
\hline & S1klık & $\mathbf{\%}$ \\
\hline Az & 4 & 23,8 \\
\hline Orta & 4 & 19,0 \\
\hline Çok & 22 & 57,1 \\
\hline Toplam & 30 & 100,0 \\
\hline
\end{tabular}

Yukarıdaki Tablo.3'de görüldüğü gibi, eğitimdeki kesintilere rağmen, İspanya'da tahsil görmesini tercih edeceklerini ifade eden ebeveynlerin oranı $(\% 57,1)$ yanında, $(\% 19,0)$ orta, $(\% 23,8)$ ise az şeklinde saptanmıştır.

Ebeveynlerle yapılan çalışmada sonuçlar aşağıdaki şekilde özetlenebilir:

- Genel olarak, göçmen ailelerin Katalan eğitim sistemine yaptıkları değerlendirme ve çocuklarının okula uyumunu olumlu olarak değerlendirmektedir. Öğretmenlerinden gördükleri özeni vurgulamaktadırlar. Bu sonucun, kendilerinin de eğitim topluluğuna katılım oranları ile yakın ilgileri olduğu açıktır. Öte yandan, PISA 2015 yılı eğitim değerlendirmesinin sonuçlarına dayanarak Convivencia Cívica Catalana'nın Katalan eğitim sistemindeki göçmen öğrencilerin sonuçlarının istatistiksel analizinin sonucu ise, Latin-Amerika kökenli (hispanoamericanos) öğrencilerin Katalan eğitim sisteminden özellikle memnun olmadığını göstermektedir. İspanyolca konuşan göçmen öğrencilerin \%29,3'ü, kendilerini Katalonya'nın eğitim kurumlarına "uyumlu" hissetmediklerini, Madrid'e oranla yaklaşık üç kat daha fazla (\%11) uyum sorunu yaşadıklarını saptamıştır (2016: 54).

-Ebeveynlerin büyük çoğunluğunun, çocuklarının eğitimini kendi ülkelerinden ziyade İspanya'da devam etmeleri ve eğitimlerini tamamlamalarını tercih etmeleri gerçeği saptanan oranlara yansımıştır. Benzer şekilde, ebeveynlerin $(\% 47,6)$ 'sı eğitimin kriz dolayısı ile zarar göreceğini düşünmesine rağmen, $(\% 57,1)$ 'si eğitimde kesinti yapılmış olsa bile, çocuklarının İspanya'da eğitim görmesini tercih etmektedir. Bu durumun istatistiklere göre, köken ülke bağlamında değişiklik gösterdiğini belirtmekte yarar vardır. Yabancı uyruklu öğrenci sayısındaki sürekli büyümenin ardından, ekonomik kriz ve yeni göç akımlarındaki küçük yavaşlama ve aile birleşmesi süreçleri, bu sayının istikrara kavuşması ve ardından düşme eğilimi göstermiştir. Bir grup uzman araştırmacının hazırladığ1 rapora göre, örneğin, Güney Amerika kökenli öğrencileriler, 2008-2009 akademik yılından bu yana sürekli azalmaktayken (altı yıldan fazla bir süredir, bu milletlerden öğrenci sayısı yarı yarıya düşmüştür) bu keskin düşüş, Afrikalı ve Asyalı öğrenci sayısındaki artışla dengelenmektedir. Bir bütün olarak yabancı uyruklu öğrencilerin krizin başlangıcı ile bugün arasındaki bileşimi önemli ölçüde değişmiştir. Ancak, belirsiz istatistikler, krizin özellikle gelecekteki eğilimlerle ilgili olarak zaten yorumlanmasını zorlaştırdığ 1 bir duruma getirdiğinden bu duruma ilişkin belirsizliği yinelemek önem arz eder (Canosa vd., 2016: 43).

Çalışma Bakanlığı tarafından veya Sosyal Refah ve Aile Departmanı tarafından aktif istihdam politikalarına yapılan kamu yatırımlarının temelde azaltılmasından dolayı, mesleki eğitim ve okuliş geçişi veya erken çocukluk dönemine ait diğer okul dışı hizmetler de iş ve istihdam departmanı gibi diğer departmanların bütçe zorluklarından etkilenmiştir. Genel olarak ekonomik krizin, yerel eğitim politikalarının ve geliştirilmesi için belediyelerin diğer idarelerden aldığı eğitim yatırımlarının azaltılmasında finansal kayıpların olduğu bir dizi faktörle açıklanmaktadır. Eğitim Departmanı, 
anaokullarının desteklenmesi, çevre için eğitim planlarının yürütülmesi veya okul dışı faaliyetlerin veya diğer eğlence programlarının teşvik edilmesi için şehir konseylerine destek sağladığı sübvansiyonları azaltmıştır (Albaigés, 2016: 74).

Eğitim sistemine yetersiz şekilde fon aktarımı vurgulamak için eğitim topluluğu içinde geniş bir fikir birliği vardır. Kamu ve kamu sübvansiyonlu özel okullardan ortak oluşan Katalonya Eğitim hizmeti, eğitim fırsatlarını eşit fırsatlarla garanti etmek için önemli kamu yatırım açıkları olduğunu ortaya koymaktadır (Síndic de Greuges_de Catalunya, 2019: 4).

Öğrencilerin özel eğitim ihtiyaçlarını daha fazla güvence altına almak (göçmen öğrencilerde bu grubun içerinde kabul edilir) için daha fazla insani, ekonomik ve maddi kaynak tahsis edilmesini gerektiren, özellikle daha fazla karmaşıklığ 1 olan kamu ve kamu sübvansiyonlu okullar bulunmaktadır (Síndic de Greuges de Catalunya, 2019: 4).

Kamu finansmanı açığı, okulların sunduğu eğitim hizmetinin bir kısmının, ailelerin katkılarıyla finanse edilmesine neden olması sebebi ile eğitim sistemimizi düzenleyen mevzuattaki temel eğitimin zorunlu ve ücretsiz verilmesi ilkeleri ile çelişen bir durumdur. Hem farklı okullara erişimde hem de kısmen ailelerin özel finansmanıyla şartlandırılmış eğitim projelerinin yapılandırılmasında önemli bir eşitsizlik faktörüdür (Síndic de Greuges de Catalunya, 2019: 4).

Bu bağlamda, mevcut eğitim desteğinin özel ihtiyaçlarını karşılamak için kaynakların sağlanmasını artırmayı amaçlayan önlemler gibi, öğrencilerin dengeli bir şekilde okula yerleştirilmesinde okulların ortak sorumluluğunu arttırmayı amaçlamaktadır. Katalonya Eğitim Hizmetini oluşturan ve 10 Temmuz tarihli 12/2009 sayılı Eğitim Yasasının (Llei 12/2009, del 10 de juliol, d'educació), 2. maddesi genel eğitim ve eğitim reformu finansmanı eğitim bütçesini GSYİH'nın \%6'sı civarında artırma ihtiyacı vurgulanmaktadır. Okulların finansman sorununu çözmek, ücretsiz eğitimi teşvik etmek ve eğitim sisteminin ayrışmasını düzeltmek için öncelikli bir konudur (Síndic de Greuges de Catalunya, 2019: 5).

- Göçmen ebeveynler çocuklarının eğitim konusuna özen göstermektedirler. Ancak, yoğun çalışma tempolarından dolayı eğitim topluluğuna katılımları orta düzeydedir. Son olarak, İspanyolca bilmeyen ebeveynlerle okul ve aile arası iletişime yardımcı olmak için bir tercümana desteği edinmek pek kolay değildir. Bazen, bu görevi üstlenmesi gereken gereken çocuklarıdır.

Genel olarak tüm İspanya'da eğitim harcamaları artmakla beraber hâlâ AB ortalamasının altında seyretmektedir. 2018 Bertelsmann Sustainable Governance Endeks'in son verilerine göre, eğitim çıktıları, güncel olmayan müfredat, eğitim-öğretim kalitesi endişeleri ve genel olarak düşük finansman nedeniyle kısmen vasattır (Bertelsmann Sustainable Governance Index, 2018).

\section{SONUÇ}

Bu çalışmada iki yönlü bir amaç takip edilmiştir. Bir yandan, Katalonya'nın göçmen eğitimine ilişkin hukukî mevzuatında yapılan düzenlemeler, diğer yandan, Katalonya'daki yabancı uyruklu öğrencilerin oran olarak okullarda artan değişimine ilişkin ortaya konan politikalar incelenmiştir.

Katalonya' da göç nispeten yenidir, politika yapıcıların yetkililer bu göç çeşitliliğini nasıl yönetecekleri konusunda mücadele etmektedirler. Katalan politika yapıcılar Fransız doktrini ile ilişkilendirilmek istememektedirler. İspanya entegrasyon modeli ne asimilasyonist ne de tam olarak çoğulcudur. Model daha çok karma, daha az tutarlı ve parçacıldır. Güçlü ve zayıf yönleri bulunmaktadır. Asimilasyon ve kültürlerarası entegrasyon modelleri arasında bir yerde bulunan bu yeni yaklaşımın 
ne anlama geldiği ise tam olarak belli değildir. Bu nedenle, bu noktada kültürlerarası eğitimin kapsamı, tanınma, karşılıklı saygı ve müfredattaki bazı marjinal değişiklikler gibi eğitim personelinin değerlerini öğretme çabalarıyla sınırlı görünmektedir; uygulama ise büyük ölçüde okulların isteklerine ve yorumlarına bağlıdır.

Önemli hususlardan biri, tarihsel olarak kültürel çeşitliliği ve buna yönelik tecrübeleri bulunmayan eğitim kadrosuna (ilk ve sürekli) eğitimlerinin verilmesi meselesiydi. Örneğin, dil ve kültür konusunda farklılık gösteren Özerk Toplulukların ve toplumda Roman vatandaşların da var olmasına rağmen, bu yaklaşım gerek Eğitim Fakültelerinde gerekse sürekli eğitimde ancak son yıllarda zenginleşebilmiştir. Yabancı uyruklu öğrencileri olan öğretmenler genellikle eğitim kaynakları aradılar ya da kültürlerarası söylemleri okul ve sınıf uygulamalarıyla donatmak için yenilediler. Aslında, söylem ve uygulama arasındaki bu orantısızlık, Katalan eğitimi sisteminin en zayıf yönlerinden biridir. Ancak, öğretmenlerin bir bölümü tarafından gerçekleştirilen yenilikler ile yavaş yavaş zorluklar aşılmaktadır.

İkinci olarak, yabancı uyruklu öğrenci sayısının en fazla olduğu okullarda kaynakların gerekli şekilde tahsis edilememesinin ötesinde, ortaya konan çözümler mevcut göç baskının bazen geçici olarak ayrıştırma eylemlerinin tasarımını veya belirli önlemlerin verimsiz olarak uygulanmasını içerdiğini göstermektedir.

Tüm söylenenlere rağmen, beklenmedik göç artışı ve göç baskısının sınıflarda etkisi Katalonya Hükümeti tarafından cevaplandırılmaya çalışılmış ve asimile edici konuşmalardan daha çok telafi edici, sosyal bütünleşme/uyum arayışı üzerine odaklanan bir kültürlerarası arayışa doğru yönelmiştir.

Manresa şehrinde yapılan küçük ölçekli anket çalışmasında yabancı uyruklu ebeveynlerin Katalan eğitim sistemi ve Katalan eğitim kurumları tarafından çocuklarının okula uyum sağlayabilmeleri için sunulan hizmetleri olumlu olarak değerlendirmelerine rağmen, bu sonucu doğru değerlendirebilmek için Katalan eğitim sistemi ile kendi köken ülkelerinde var olan eğitim sistemiyle bir karşılaştırma üzerinden oluşturulduğunu gözden kaçırmamak gerekir. Ek olarak, yapılan çalışmanın örneklem sınırlılığından dolayı sonuçlar genellenemez. Diğer bir ifade ile Katalonya'nın bütününü içeren bir çalışma değildir.

Son olarak, önemli sayıda yabancı uyruklu öğrenciye sahip okulların ihtiyaçları ile tahsis edilen kaynaklar arasında hâlâ dengesizlikler olduğunu söylemek mümkündür. Ancak, on yıldan biraz daha fazla bir sürede hem söylemde hem uygulamada önemli bir ilerleme kaydedilmiştir.

\section{KAYNAKLAR}

Albaigés, B. (2016). Les Polítiques educatives locals en temps de crisis, Gabinet de Premsa y Comunicació de la Diputació de Barcelona. [Online] https://www1.diba.cat/uliep/pdf/56340.pdf [Erişim Tarihi: 23.03.2019].

Artola, Antidio Martínez de L. (2009). Políticas Autónomicas De Integración De Inmigrantes: La Educación, Revista Española de Educación Comparada, 15. [Online] http://revistas.uned.es/index.php/REEC/article/view/7510/7178 [Erişim Tarihi : 11.03.2018]. 
Barrero, R. Z. and Witte, de N. (2007). "Spanish Approaches to the Management of Cultural Diversity in Compulsory Education", Grup de Recerca sobre Immigració i Innovació Política (GRIIP). Department of Social and Political Science, Universitat Pompeu Fabra. [Online] https://www.upf.edu/documents/3329791/3455370/griip-emilie_wp3.pdf/e9e436fa-57b8-4538-a9af4e99e495e6b8 [Erişim Tarihi: 20.11.2018].

Besalú, X. (2006). “El Plan Para La lengua y La Cohesión Social (Plan LIC) del gobierno de Cataluña”, Revista Interuniversitaria de Formación del Profesorado, 20(2), ss.45-68.

Calvet, Núria L. (2011). Políticas Educativas De Inmigración En Cataluña y Su Reflejo En Una Escuela, Instituto de Migraciones, Andalucia, Granada. [Online] https://dialnet.unirioja.es/descarga/articulo/4051225.pdf [Erişim Tarihi: 01.04.2018].

Canosa, Miquel Ángel A., Jordi, B. and Climent-Fernando, V. (2016). Report on the integration of immigrants in Catalonia 2015, Generalitat de Catalunya, Obra Social, La Caixa.

Canosa, Miquel Ángel A. (2011). Políticas de Acogida Escolar En Catalunya. Una Aproximación Crítica", Población Inmigrante y Escuela: Conocimientos y Saberes de Investigación, (Eds. F. Javier, García Castaño y Silvia, Carrasco Pons), Colección Estudios Creade, N. 8, Ministerio de Educación, Gobierno de España, Instituto de Formación del Profesorado, Investigación e Innovación Educativa (IFIIE), ss.535-547.

Casas Mínquez, F. (2004). Acerca de La Integración y Sus Problemas. Bits: Boletín informativo trabajo social. №.7. [Online] http://www.uclm.es/bits/sumario/37.asp [Erişim Tarihi: 28.11.2018].

Catalunya del Síndic. (2016). La Segregación Escolar En Cataluña (II): Condiciones De Escolarización. [Online]

https://www.sindic.cat/site/unitFiles/4227/Informe\%20segregacio\%20escolar_II_condicions_escolari tzacio_cast_ok.pdf [Erişim Tarihi: 30.03.2018].

Ceceli, K. S. (2012). Çokkültürcülük Politikalarından Entegrasyon Politikalarına Geçiş: Hollanda'daki Türkiye Kökenli Göçmenler Üzerine Bir İnceleme, Hacettepe Üniversitesi Sosyal Bilimler Enstitüsü, Yüksek Lisans Tezi.

Convivencia Cívica Catalana. (2016). Los Inmigrantes en el Sistema Educativo en Cataluña: Perfil Resultados Académicos y Valoraciones. Análisis PISA en Base a PISA 2015. [Online] http://www.amesfps.com/los_inmigrantes_en_el_sistema_educativo_de_cataluna.pdf [Erişim Tarihi: 03.05.2018].

Escandell, José Ramón V. (2003). Hacia Una Escuela Multicultural La Presencia Creciente De Inmigrantes En El Sistema Educativo Español. [Online] https://www.uv.es/cuadernosgeo/CG72_157_172.pdf [Erişim Tarihi: 05.02.2018].

European Commission, Emilie Project Final Report. (2009). A European Approach to Multicultural Citizenship. Legal Political and Educational Challenges. [Online] https://cordis.europa.eu/documents/documentlibrary/123869731EN19.doc [Erişim Tarihi :20.02.2018].

Generalidat de Catalunya, Estadística de l'ensenyament. [Online] http://ensenyament.gencat.cat/ca/departament/estadistiques/estadistiques-ensenyament/ [Erişim Tarihi: 02.02.2019]. 
Generalitat de Catalunya, Institut d'Estadística de Catalunya. (2018). Extranjeros con autorización de residencia. Por país de nacionalidad. [Online]https://www.idescat.cat/pub/?id=aec\&n=272\&lang=es\&t=2016 [Erişim Tarihi: 07.04.2018].

Generalitat de Catalunya. (2018). Pla de Ciutadania i Migracions 2017-2020. [Online] http://premsa.gencat.cat/pres_fsvp/AppJava/notapremsavw/303287/ca/llum-verda-ciutadaniamigracions-2017-2020-construir-societat-inclusiva.do [Erişim Tarihi: 18.01.2018].

Generalitat de Catalunya. (2017). Institut d'Estadística de Catalunya, Dades població Catalunya. [Online] http://www.idescat.cat/poblacioestrangera/?b=0 [Erişim Tarihi: 27.04.2018].

Generalitat de Catalunya, Departament d'ensenyement. (2017). El Projecte de convivència. [Online] http://xtec.gencat.cat/web/.content/alfresco/d/d/workspace/SpacesStore/0004/01d4f408-7a27-4017bdd0-d63cb95b214f/PdC.pdf ss.5-13 [Erişim Tarihi: 02.05.2018).

Generalitat de Catalunya, Department de Treball Afer Socials i Families. (2017). Secretaría d'Igualtat, Migracions y Cuitadania. Xifres provisonals a 1 de Juliol 2017. [Online] http://www.idescat.cat/poblacioestrangera/?b=0\&lang=en [Erişim Tarihi: 27.04.2018].

Generalitat de Catalunya. (2016). Treball, Afers socials i Famílies ha ajudat més de 19.000 persones el 2016 a regularitzar la seva sitaució administrativa. Nota de prensa, Barcelona.

Generalitat de Catalunya, Departament de Treball, Afers Socials y Families Secrtaría d'Igualtat, Migracions y Cuitatania. (2016a). Pla De Cuitadania I De Les Migraciones 2017-2020. [Online] http://premsa.gencat.cat/pres_fsvp/docs/2016/10/21/13/30/331f595b-aebd-4109-a3cb7d7349928604.pdf [Erişim Tarihi: 18.03.2018].

Generalitat de Catalunya, Departament d'Educació. (2009). Pla Per a la Llengua I La Cohesió Social. [Online] http://cmaps.cmappers.net/rid=1HDMMPDQ7-6DSHB5 6KT/Pla\%20per\%20la\%20Llengua\%20i\%20la\%20Cohesi\%C3\%B3\%20Social.pdf (Erişim Tarihi: 15.03.2018).

Generalitat de Catalunya, Departament de Presidencia Oficia Comunicación de Govern. (2006). El Govern Assoleix un Acord per al Pacte Nacional per a l'Educació, [Online] http://www.gencat.cat/acordsdegovern/20060314/20060314_AG.pdf [Erişim Tarihi: 15.03.2018].

Generalitat de Catalunya, Departament d'Educació. (2004). Pla per a la llengua I La Cohesió Social. [Online] http://www.xtec.cat/serveis/eap/e3900133/pdf/cohesio.pdf. [Erişim Tarihi: 04.04.2018].

Generalitat de Catalunya, Departament d'Ensenyement. (2003). Pla d'actuació per a l'alumnat de nacionalitat estrangera 2003-2006. [Online] http://www.xtec.cat/sgfp/llicencies/200203/memories/jribera/WEBTAES/novetats/plactuacio.pdf [Erişim Tarihi: 08.04.2018].

Generalitat de Catalunya, Departament d'Ensenyament. (1992). Currículum. Educació primària. [Online] http://educacio.gencat.net/extranet/dogc/decret_223_1992.html [Erişim Tarihi: 19.11.2017].

Generalitat de Catalunya, Departament d'Ensenyament. (1992a). Educació Secundària Obligatòria. Ordenació Curricular. [Online] http://educacio.gencat.net/extranet/dogc/decret_223_1992.html [Erişim Tarihi: 19.11.2017].

Gutiérrez, Enrique Javier D. (2012). Educación Intercultural: Manual de Grado, Malaga: Ediciones Aljibe. 
González, María José A. (2013). La Enseñanza del Español Al Alumnado Inmigrante: Análisis de Los Principales Programas en el Contexto Escolar, Revista Educación y Futuro Digital, No. 7, ss.70-92. [Online]

http://redined.mecd.gob.es/xmlui/bitstream/handle/11162/119007/EYFD_76.pdf?sequence=1\&isAllo wed=y [Erişim Tarihi:29.04.2017].

Instituto Nacional de Estadística. (2018). Población Residente en España. [Online] http://www.ine.es/dyngs/INEbase/es/operacion.htm?c=Estadistica_C\&cid=1254736176951\&menu=u ltiDatos\&idp=1254735572981 [Erişim Tarihi: 20.09.2018].

Kaiser, B. and Kaya, A. (2016). The Transformation and Europeanization of Migration Policy in Turkey: Multiculturalism, Republicanism and Alignment, Turkish Migration Policy, (ed. Ibrahim Sirkeci and Barbara Pusch), London: Transnational Press.

Katalonya Ulusal İstatistik Kurumu. [Online] https://www.idescat.cat/emex/?id=081136\&lang=es [Erişim Tarihi: 20.09.2018].

Kymlicka, W. (2012). Çok Kültürlülük: Başarı, Başarısızlık ve Gelecek, (Fatih Öztürk, Çev.), İstanbul Üniversitesi Hukuk Fakültesi Mecmuası, Cilt 70, Sayı: 2, Sayfa: 297-332.

Kymlicka, W. (1998). Çokkültürlü Yurttaşlık, (Çev., Abdullah Yılmaz), İstanbul: Ayrıntı Yayınları.

Migrant Integration Policy Index (2015). Spain Key Findings. [Online] http://www.mipex.eu/spain [Erişim Tarihi: 23.03.2019].

Ministerio de Educación, Cultura y Deporte. (2018). Estadística de las Enseñanzas no Universitarias. Datos avance 2016-2017. [Online] https://www.mecd.gob.es/servicios-al-ciudadano-

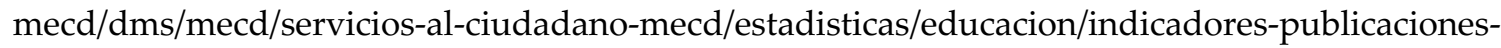
sintesis/datos-cifras/Datosycifras1718esp.pdf [Erişim Tarihi: 04.11.2018].

Navarro, V. (2009). El sistema educativo clasista en Cataluña. [Online] http://www.vnavarro.org/?p=3085 [Erişim Tarihi: 28.01.2018].

Özer, Y. (2015). Türkiye ve Fransa Örnekleriyle Uluslararası Göç ve Yabancı Düşmanlığı, İstanbul: Derin Yayınları.

Öztürk, Özgür G. (2016). İspanya Göç Politikaları ve Göçmen Hayatlar: İspanya Örneği Türkiye İçin Bir Model Olabilir mi?, Turkish Journal Of Population Studies, 36, ss.103-135.

Síndic de Greuges de Catalunya (2019). Pacte contra la segregació escolar a Catalunya: un compromís per a l'èxit educatiu. [Online] https://www.esparreguera.cat/fitxers/regidors/0_5_05_pacte_contra_la_segregacio_escolar.pdf [Erişim Tarihi: 23.03.2019].

Taylor, C. (1992). Multiculturalism and The Politics of Recognition, New Jersey: Princeton University Press.

Tunçay, F. (2016). Bask Ülkesi ve Katalonya: Dil Taleplerine İlişkin Yasama Faaliyetleri, Assam Uluslarası Hakemli Dergi, Cilt III, Sayı 5, ss. 45 - 56.

Vila, I., Canal, I. y Mayans, P (2009). Las Aulas de Acogida de la Educación Primeria de Cataluña el Curso 2005-2006: Sus Efectos Sobre el Conocimiento de Catalán y La Adaptación Escolar, Infancia y 
Aprendizaje, Journal for the Study of Education and Develoment, Routledge: Taylor \& Francis Group, 32(3), ss.307-327.

Zapata, R., Zaragoza J. W. and De N. (2007). Diversity, Migration and Citizenship. Approaches for Diversity Management in 21st Century in Spain, Grup de Recerca Interdiciplinari Sobre Immigració

(Gritim) Department of Social and Political Science Universitat de Pompeu Fabra. [Online] https://www.researchgate.net/publication/265030463_DIVERSITY_MIGRATION_AND_CITIZENS HIP_APPROACHES_FOR_DIVERSITY_MANAGEMENT_IN_21_ST_CENTURY_IN_SPAIN [Erişim Tarihi: 27.09.2018].

\section{EKLER}

\section{EK 1:}

ANKETE KATILAN AİLELERIN GENEL VERILERI

\begin{tabular}{|c|c|c|c|c|c|}
\hline Genel veriler & Toplam & Fas & Romanya & G.Amerika & Hindistan \\
\hline \multicolumn{6}{|l|}{ Okula giden çocuk sayısı } \\
\hline 1 çocuk & 8 & 2 & 3 & 2 & 1 \\
\hline 2 çocuk & 19 & 12 & 2 & 2 & 3 \\
\hline 3 çocuk & 3 & 1 & 1 & 1 & 0 \\
\hline 4 çocuk & 0 & 0 & 0 & 0 & 0 \\
\hline \multicolumn{6}{|l|}{ Akademik seviye } \\
\hline Ana okulu & 4 & 3 & 0 & 1 & 0 \\
\hline İlkokul & 12 & 7 & 2 & 4 & 0 \\
\hline Zorunlu ortaokul & 11 & 5 & 4 & 1 & 1 \\
\hline Bachillerato/Lise & 3 & 0 & 3 & 0 & 0 \\
\hline $\begin{array}{l}\text { Mesleki başlangıç yeterlilik programı } \\
\text { (PCPI) }\end{array}$ & 0 & 0 & 0 & 0 & 0 \\
\hline Mesleki eğitim & 0 & 0 & 0 & 0 & 1 \\
\hline \multicolumn{6}{|l|}{ Öğretim kurumunun türü: } \\
\hline Kamu okulu & 26 & 15 & 6 & 3 & 2 \\
\hline Kamu sübvansiyonlu okul & 2 & 1 & 0 & 1 & 0 \\
\hline Özel & 2 & 0 & 1 & 0 & 1 \\
\hline \multicolumn{6}{|l|}{ Annenin akademik seviyesi } \\
\hline Tahsili yok/ilkokulu tamamlamamış & 3 & 2 & 1 & 0 & 0 \\
\hline İlkokul & 3 & 2 & 1 & 0 & 0 \\
\hline Zorunlu ortaokul & 19 & 3 & 12 & 2 & 2 \\
\hline Mesleki eğitim & 1 & 0 & 1 & 0 & 0 \\
\hline Üniversite & 4 & 0 & 2 & 2 & 0 \\
\hline \multicolumn{6}{|l|}{ Babanın akademik seviyesi } \\
\hline Tahsili yok/ilkokulu tamamlamamış & 4 & 4 & 0 & 0 & 0 \\
\hline İlkokul & 4 & 2 & 1 & 1 & 0 \\
\hline Zorunlu ortaokul & 18 & 1 & 13 & 2 & 2 \\
\hline Mesleki eğitim & 1 & 0 & 1 & 0 & 0 \\
\hline Üniversite & 3 & 2 & 0 & 1 & 0 \\
\hline
\end{tabular}




\section{EK 2:}

\section{ANKETE SORULARININ TERCÜMESI}

Seçtiğiniz cevap karşılık gelen ilgili kutucuğu veya sayıyı çarpı ile işaretleyiniz. Eğer yanlış işaretlerseniz lütfen yanlış cevabı tamamen siliniz ve doğruyu işaretleyiniz. Başka bir açıklama olmadıkça lütfen her bir soruya tek bir cevap işaretleyiniz. Bize verdiğiniz bilgiler gizli tutulacak olup asla ifşa edilmeyecektir.

İSIM:

TARIH:

ELEKTRONIK POSTA

TELEFON

IMZA:

\section{GENEL VERILLER}

\section{Bu formu kim dolduruyor?}

Baba $\square$ Anne $\square$ Her ikisi

2. Okula giden çocuk sayısı:

3. Çocukların yaşları? __yaşında __yaşında__yaşında

4. Hangi okulda okuyorlar?
Ana okulu
İlkokuЏ Zorunlu ortaokul
Lise
Mesleki eğitim
Mesleki başlangıç yeterlilik programı (PCPI)

\section{5. Çocuğunuzun okuduğu öğretim kurumunun türü:}

Devlet okul Kamu sübvangeli Özel okul

\section{Annenin milliyeti nedir?}

7. Babanın milliyeti nedir?

\section{Annenin tahsil durumu nedir?}

Tahsili yok/ilkokulu tamamlalimamış İlkokul $\square$ Mesleki eğitim almış $\quad$ Ortaokul/Lise $\quad \square \quad$ Universite

\section{Babanın tahsil durumu nedir?}

Tahsili yok/ilkokulu tamamlanglımış

İlkokul $\square \quad$ Mesleki eğitim almış Ortaokul/Lise

Üniversite

10. Çocuğunuzun okuduğu öğretim kurumunu seçmenizde aşağıdaki nedenlerden her birinin ne derece etkili olduğunu değerlendiriniz (1. Az, 2. Orta, 3. Çok)

\begin{tabular}{|l|l|l|l|}
\hline Eve veya işe yakın olması & 1 & 2 & 3 \\
\hline Kamu sübvansiyonlu veya özel bir okul & 1 & 2 & 3 \\
\hline Eğitim kadrosu kalitesi & 1 & 2 & 3 \\
\hline Hizmetler ve donanımlar & 1 & 2 & 3 \\
\hline
\end{tabular}




\begin{tabular}{|l|l|l|l|}
\hline Bana uyan değerleri yansitiyor & 1 & 2 & 3 \\
\hline Bu kurumda okuyan öğrencilerin türü & 1 & 2 & 3 \\
\hline Ülkemdeki ailelerin bu kurumu seçmesi & 1 & 2 & 3 \\
\hline Bu kurumun disiplininden ötürü & 1 & 2 & 3 \\
\hline Başka neden ile:
\end{tabular}

\section{II. ÖĞRETIM KURUMU İLE İLETIŞIMM DERECESİ VE EĞİTIM}

\section{CAMIASINA KATILMA}

1. Okul Müdürünü tanıyor musunuð? $\mathrm{Ev} \square \quad$ Hayır

2. Danışmanı tanıyor musunuz? $\square \quad$ Eve $\square \quad$ Hayır

3. Geçtiğimiz eğitim öğretim yılı boyunca çocuğunuzun öğretmeni ile konuştunuz mu? Konuştuysanız kaç defa olduğunublelirtiniz $\quad \square \quad$ Evet

_ Defa_ Hayır

4. Öğretmen ile konuşmanızdaki gerekçeler nedir?

Kendi girişimim $\square \quad$ Öğretmenin girişimi

Çocuğun uygunsuz

Diğer

5. Okulda neler olduğuna dair sürekli bilgi alıyor musunuz (etkinlikler, davetler, toplantılar, düzenlemeler, günler vs.)? $\square$ Evet $\square$ Hayır

6. Okulun idari kadrosunu taniyor musuhuz? Evet $\square$ Hayır

7. Okul ile herhangi iletişim sorunu yaşadınız mı $\quad \square \quad$ Evet $\square \quad$ Hayır

8. Eğitim kurumunda AMPA'y ${ }^{23}$ tanıyormulunuz? Evet $\square \quad$ Hayır

9. Sizin bakış açınıza göre öğrencinin anne ve babasının AMPA'ya katılım derecesi nedir?

Düşük $\square$ Orta $\square$ Yüksek Fikrim Yok

10. Siz AMPA'ya üye misiniz? $\square \quad$ Evet $\square \quad$ Hayır

11. Eğer AMPA'ya üye iseniz katılım düzeyiniz nedir?

Düşük $\square$ Orta $\square \quad$ Yüksel $\square \quad$ Açılama Yok

${ }_{23}$ AMPA: Las Asociaciones de Madres y Padres de Alumnos.

Öğrenci Anne ve Babaları Derneği 
12. Eğer AMPA'ya üye değil iseniz katılmama nedeniniz nedir?

Haberim Yok $\square$ Beni İlgilendirmlybr Zamanım yok

Diğer (belirtiniz)

\begin{tabular}{|l|l|l|l|}
\hline $\begin{array}{l}\text { 13. Aşağıdaki etkinliklere katılımınızın çocuğunuzun eğitimini ne derece } \\
\text { geliştirdiğini düşündüğ̈ünüzü değerlendiriniz (1. Az, 2. Orta, 3. Çok) }\end{array}$ \\
\hline Okul etkinliklerine katılım (eğlenceler, tiyatro) & 1 & 2 & 3 \\
\hline Veli toplantılarına katılım & 1 & 2 & 3 \\
\hline Eğitmen veya öğretmen bireysel ziyaretleri & 1 & 2 & 3 \\
\hline Okul idaresi temsilcilerinin seçilmesi & 1 & 2 & 3 \\
\hline Ev ödevlerini yapmada yardımcı olma & 1 & 2 & 3 \\
\hline Kendi çocuğunun arkadaşının velileri ile tanışma & 1 & 2 & 3 \\
\hline
\end{tabular}

\section{BILLGIYYE ERIŞMEDE KOLAYLIK}

\begin{tabular}{|l|l|l|l|}
\hline $\begin{array}{l}\text { Bilgiye erişmede kolaylık hususunda memnuniyet derecenizi değerlendiriniz } \\
\text { (1. Az, 2. Orta, 3. Çok) }\end{array}$ & 3 \\
\hline $\begin{array}{l}\text { Okul öğrenimi sürecinde işlemler ve kabul kriterleri } \\
\text { hususunda bilgiye erişim kolaylı̆̆ mevcut. }\end{array}$ & 1 & 2 & 3 \\
\hline $\begin{array}{l}\text { Öğrenim denkliği tanımada bilgiye erişim kolaylı̆̆ı } \\
\text { mevcut. }\end{array}$ & 1 & 2 & 3 \\
\hline Eğitim kurumunu değiştirmede kolaylık mevcut. & 1 & 2 & 3 \\
\hline İspanyolca lisanını bilmeyen veliler için tercüman mevcut. & 1 & 2 & 3 \\
\hline
\end{tabular}

\section{EĞİTIM KURUMU İLE İLGİLI MEMNUNIYYT DERECESİ}

\begin{tabular}{|l|l|l|l|}
\hline $\begin{array}{l}\text { 1. Aşağıdaki konularda çocuğunuzun aldığı eğitim kapsamında memnuniyet } \\
\text { derecenizi değerlendiriniz (1. Az, 2. Orta, 3. Çok) }\end{array}$ \\
\hline Okuldaki çalışma ortamı & 1 & 2 & 3 \\
\hline Ö̆ğretmenlerin öğretme şekli & 1 & 2 & 3 \\
\hline Öğrencilerin aldı̆̆ hazırlıklar & 1 & 2 & 3 \\
\hline Velilerin okula katılımı & 1 & 2 & 3 \\
\hline Okul idaresinin işlevi & 1 & 2 & 3 \\
\hline Aileler ve öğretmenler arasında iletişim & 1 & 2 & 3 \\
\hline Öğretmenin ailelere gösterdiği özen & 1 & 2 & 3 \\
\hline $\begin{array}{l}\text { Eğitim kurumunun donanımı, araç ve gereçleri (yemekhane, spor } \\
\text { salonu, kitaplık, vs.) }\end{array}$ & 1 & 2 & 3 \\
\hline Eğitim kurumunun yansıttı̆̆ı değerler & 1 & 2 & 3 \\
\hline Çocuğumun aldı̆̆ eğitim beklentilerimi karşılıyor & 1 & 2 & 3 \\
\hline
\end{tabular}

\section{BEKLENTILER}

\section{Aşağıdaki ifadelere katılma veya katılmama düzeyinizi işaretleyiniz}

(1. Katılmıyorum, 2. Kayıtsız, 3. Katılıyorum)

Çocuğumun öğretmenlerinin sadece akademik güçlüklere değil aynı zamanda kişilere, sevgiye ve birlikte yaşamaya da bakmasını

\begin{tabular}{|l|l|l}
1 & 2 & 3
\end{tabular}




\begin{tabular}{|l|l|l|l|}
\hline umuyorum & & & \\
\hline $\begin{array}{l}\text { Eğer çocuğum zaten okula gidiyor ise okul ile iletişime geçmeye } \\
\text { gerek yoktur. }\end{array}$ & 1 & 2 & 3 \\
\hline $\begin{array}{l}\text { Irkçılığın, yabancı düşmanlığının ve ayrımcılı̆̆ın önüne geçilmesi } \\
\text { hususunda öğretim kurumları girişimlerde bulunmalıdır. }\end{array}$ & 1 & 2 & 3 \\
\hline $\begin{array}{l}\text { Karar verme sırasında eğitim kurumlarında aileler ile görüşmek } \\
\text { üzere kendilerine ilgi gösterilmelidir. }\end{array}$ & 1 & 2 & 3 \\
\hline $\begin{array}{l}\text { Zorunlu eğitimi tamamlandığında oğlumun çalışmasını } \\
\text { isterim (Zorunlu Orta Öğretim son aşama veya ilk aşama } \\
\text { mesleki eğitim) }\end{array}$ & 1 & 2 & 3 \\
\hline $\begin{array}{l}\text { Zorunlu eğitimi tamamlandığında kızımın çalışmasını isterim } \\
\text { (Zorunlu Orta Öğretim son aşama veya ilk aşama mesleki eğitim) }\end{array}$ & 1 & 2 & 3 \\
\hline $\begin{array}{l}\text { Okul aşamasını tamamlandığında oğlumun çalışmasını isterdim } \\
\text { (Bachillerato veya mesleki eğitim) }\end{array}$ & 1 & 2 & 3 \\
\hline $\begin{array}{l}\text { Okul aşaması tamamlandığında kızımın çalışmasını isterim } \\
\text { (Bachillerato veya mesleki eğitim) }\end{array}$ & 1 & 2 & 3 \\
\hline Oğlumun Üniversitede okumasını isterim & 1 & 2 & 3 \\
\hline Kızımın Üniversitede okumasını isterim & 1 & 2 & 3 \\
\hline $\begin{array}{l}\text { Tahsili tamamladıktan sonra oğlumun ülkeme geri dönmesini } \\
\text { isterim }\end{array}$ & 1 & 2 \\
\hline Tahsili tamamladıktan sonra kızımın ülkeme geri dönmesini isterim & 1 & 2 & 3 \\
\hline Oğlumun Avrupa'da bir mesleği icra etmesini isterim & 1 & 2 & 3 \\
\hline Kızımın Avrupa'da bir mesleği icra etmesini isterim & 1 & 2 & 3 \\
\hline Oğlumun İspanya'da bir mesleği icra etmesini isterim & 1 & 2 & 3 \\
\hline Kızımın İspanya'da bir mesleği icra etmesini isterim & 3 \\
\hline
\end{tabular}

\begin{tabular}{|c|c|c|c|}
\hline $\begin{array}{l}\text { Aşağıdaki ifadelere katılma veya katılmama düzeyinizi işaretleyiniz } \\
\text { 1. Katılmıyor, 2. Kayıtsız, 3. Katılıyor) }\end{array}$ & & & \\
\hline Devlet idaresi eğitimde kesintiler yapmamalıdır. & & & 3 \\
\hline $\begin{array}{l}\text { eki kesintilere rağmen çocuğumun İspanya'da tahsil görmesini } \\
\text { erim }\end{array}$ & & & 3 \\
\hline Krizden dolayı eğitim zarar görecek. & 1 & & 3 \\
\hline $\begin{array}{l}\text { Gelecekteki eğitim hayatlarında çocuklarıma gıda yardımı } \\
\text { yapılmamasından korkuyorum }\end{array}$ & 1 & 2 & 3 \\
\hline $\begin{array}{l}\text { Gelecekteki eğitim hayatlarında } \\
\text { yapılmamasından korkuyorum }\end{array}$ & 1 & 2 & 3 \\
\hline $\begin{array}{l}\text { Gelecekteki eğitim hayatlarında çocuklarıma burs verilmemesinden } \\
\text { korkuyorum }\end{array}$ & 1 & & 3 \\
\hline
\end{tabular}

